\title{
DURATION OF ACTION OF NEOSTIGMINE IN MAN
}

\author{
Casey D. Blitt, B.J. Moon, and C. Dean Kartchner ${ }^{\circ}$
}

There ARE ONLY LIMITED DATA as to the duration of action of neostigmine in man. At the present time an assay for the detection at clinical blood levels has not been developed. This study was conceived to determine the duration of action of two commonly used dosages of neostigmine in man.

\section{METHODS}

This study was approved by the Human Subjects Committee and written consent was obtained prior to anaesthesia. The subjects of the study were 42 unpremedicated surgical patients, ASA status I, mean age 30.1 years ( \pm SE 1.4) with a mean body surface area of $1.67 \mathrm{~m}^{2}$ ( $\pm \mathrm{SE} 0.026$ ). Anaesthesia was induced with halothane and 60 per cent nitrous oxide and oxygen. Occasionally a small amount of sodium thiopentone was used to facilitate induction of anaesthesia. No other drugs were administered. The trachea was intubated without the use of muscle relaxants. End tidal halothane was measured with a Beckman LB2 infrared analyzer and maintained between 0.33 and 0.74 per cent. End tidal carbon dioxide was also measured using an infrared analyzer and was maintained between 36 and 42 torr. Oesophageal temperature ranged between 35.1 and $37.2^{\circ} \mathrm{C}$. The ulnar nerve was stimulated at the wrist using a Grass S88 Nerve Stimulator and 23-gauge thin walled needles. A supramaximal pulse of 0.1 milliseconds duration and $0.25 \mathrm{~Hz}$ was chosen to avoid repetitive excitation of the nerve. ${ }^{1}$ The force of thumb adduction produced by this stimulation was transmitted through a force displacement transducer of the boomerang type ${ }^{2}$ and recorded on a Brush recorder.

A control group of 12 patients received d-tubocurarine $4 \mathrm{mg} / \mathrm{m}^{2}$ body surface area after end tidal halothane concentration had remained constant for 20 minutes (Table I). This dose of d-tubocurarine was chosen in order to produce less than 100 per cent twitch depression in control patients (Figure 1). The twitch depression produced by this dose of d-tubocurarine was measured. Group I ( 15 patients - low dose neostigmine) was given $1.2 \mathrm{mg} / \mathrm{m}^{2}$ BSA neostigmine and after intervals of $60,75,90$, and $120 \mathrm{~min}$ d-tubocurarine $4 \mathrm{mg} / \mathrm{m}^{2}$ BSA was administered. Only one dose of d-tubocurarine was used for each patient. The twitch depression produced by d-tubocurarine administration was measured at each time interval. Group II ( 15 patients - high dose neostigmine) was given $2.4 \mathrm{mg} / \mathrm{m}^{2}$ BSA of neostigmine and after intervals of $60,90,120$, and $180 \mathrm{~min}$ d-tubocurarine $4 \mathrm{mg} / \mathrm{m}^{2}$ was given. Again only one dose of d-tubocurarine per patient was used. Twitch depression for this group also was measured at each time interval. Administration of neostigmine

'Department of Anesthesiology, University of Arizona College of Medicine, Tucson, Ariz. 85724, U.S.A. 
TABLE I

\begin{tabular}{|c|c|c|c|}
\hline & $N$ & $\begin{array}{l}\text { Mean dtc } \\
\text { dose }(\mathrm{mg})\end{array}$ & $\begin{array}{l}\text { Time (min.) } \\
\text { after neo. adnı. } \\
\text { to dtc adm. }\end{array}$ \\
\hline Control group & 12 & 6.60 & - \\
\hline $\begin{array}{l}\text { Group 1-Low dose neostigmine } \\
\qquad\left(1.2 \mathrm{mg} / \mathrm{m}^{2}\right)\end{array}$ & $1: i$ & 6.66 & $(i 1), 75,90,120$ \\
\hline $\begin{array}{c}\text { Group 2-High dose neostigmine } \\
\qquad\left(2.4 \mathrm{mg} / \mathrm{m}^{2}\right)\end{array}$ & $1 \%$ & (i. 72 & $(60, ! 90,120,1 \times 0$ \\
\hline
\end{tabular}

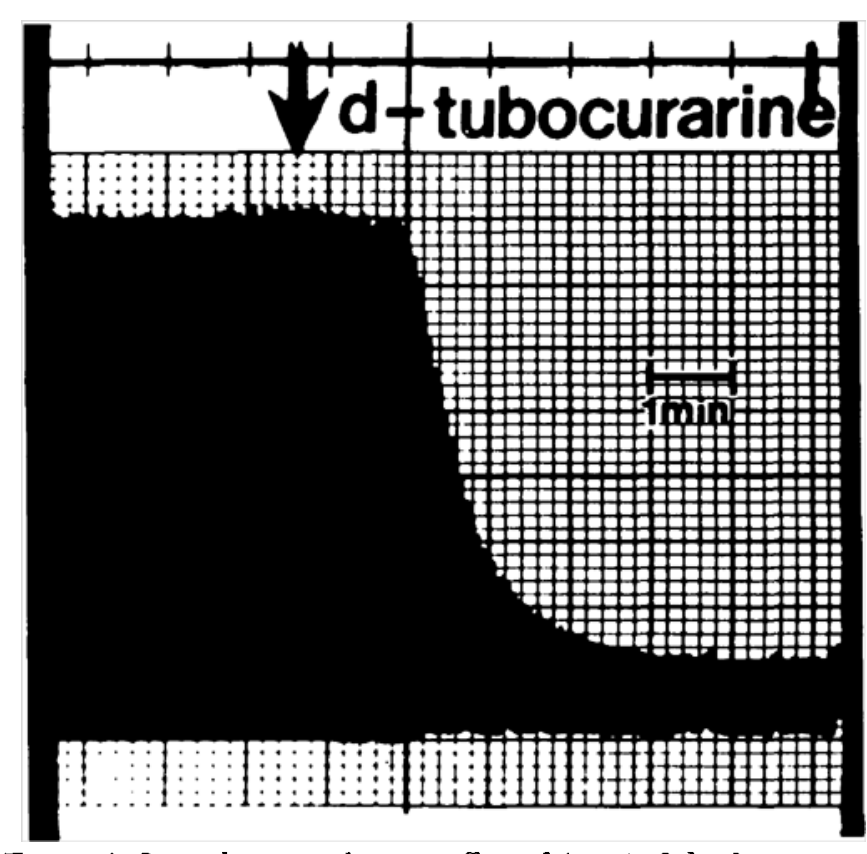

Figure 1. Control tracing showing effect of $4 \mathrm{mg} / \mathrm{m}^{2} \mathrm{~d}$-tubocurarine.

was always preceded by atropine sulfate.

The time interval between neostigmine and d-tubocurarine administration resulting in the same degree of twitch depression as the controls (d-tubocurarine only) was determined by linear regression analysis. This time interval was assumed to be the duration of action of neostigmine. Data were also analyzed using analysis of variance, Duncan multiple ranges test, and difference of means t-test.

\section{Results}

Four $\mathrm{mg} / \mathrm{m}^{2}$ of d-tubocurarine resulted in 67.8 ( \pm SE 3.9 ) per cent twitch depression (Table II). Prior administration of $1.2 \mathrm{mg} / \mathrm{m}^{2}$ BSA of neostigmine (average dose $2.00 \mathrm{mg}$ ) impaired the ability of d-tubocurarine to produce twitch 
TABLE II

\begin{tabular}{|c|c|c|c|c|}
\hline & $\begin{array}{l}\text { Dose of neo. } \\
\mathrm{mg} / \mathrm{m}^{2} \mathrm{BSA}\end{array}$ & $\mathrm{N}$ & $\begin{array}{l}\text { Time (min.) } \\
\text { after neo. adm. } \\
\text { to dtc. adm. }\end{array}$ & $\begin{array}{c}\% \text { twitch } \\
\text { depression } \\
\text { (mean } \pm \text { S.E.) }\end{array}$ \\
\hline Control group & - & 12 & - & $67.8 \pm 3.9$ \\
\hline Group 1 & $\begin{array}{l}1.2 \\
1.2 \\
1.2 \\
1.2\end{array}$ & $\begin{array}{l}5 \\
4 \\
3 \\
3\end{array}$ & $\begin{array}{r}60 \\
75 \\
90 \\
120\end{array}$ & 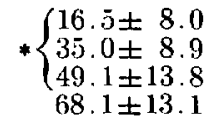 \\
\hline Group 2 & $\begin{array}{l}2.4 \\
2.4 \\
2.4 \\
2.4\end{array}$ & $\begin{array}{l}4 \\
5 \\
3 \\
3\end{array}$ & $\begin{array}{r}60 \\
90 \\
120 \\
180\end{array}$ & * $\left\{\begin{array}{l}13.4 \pm 5.6 \\
42.2 \pm 5.9 \\
53.1 \pm 14.9 \\
51.3 \pm 15.9\end{array}\right.$ \\
\hline
\end{tabular}

*Statistically different from contral.

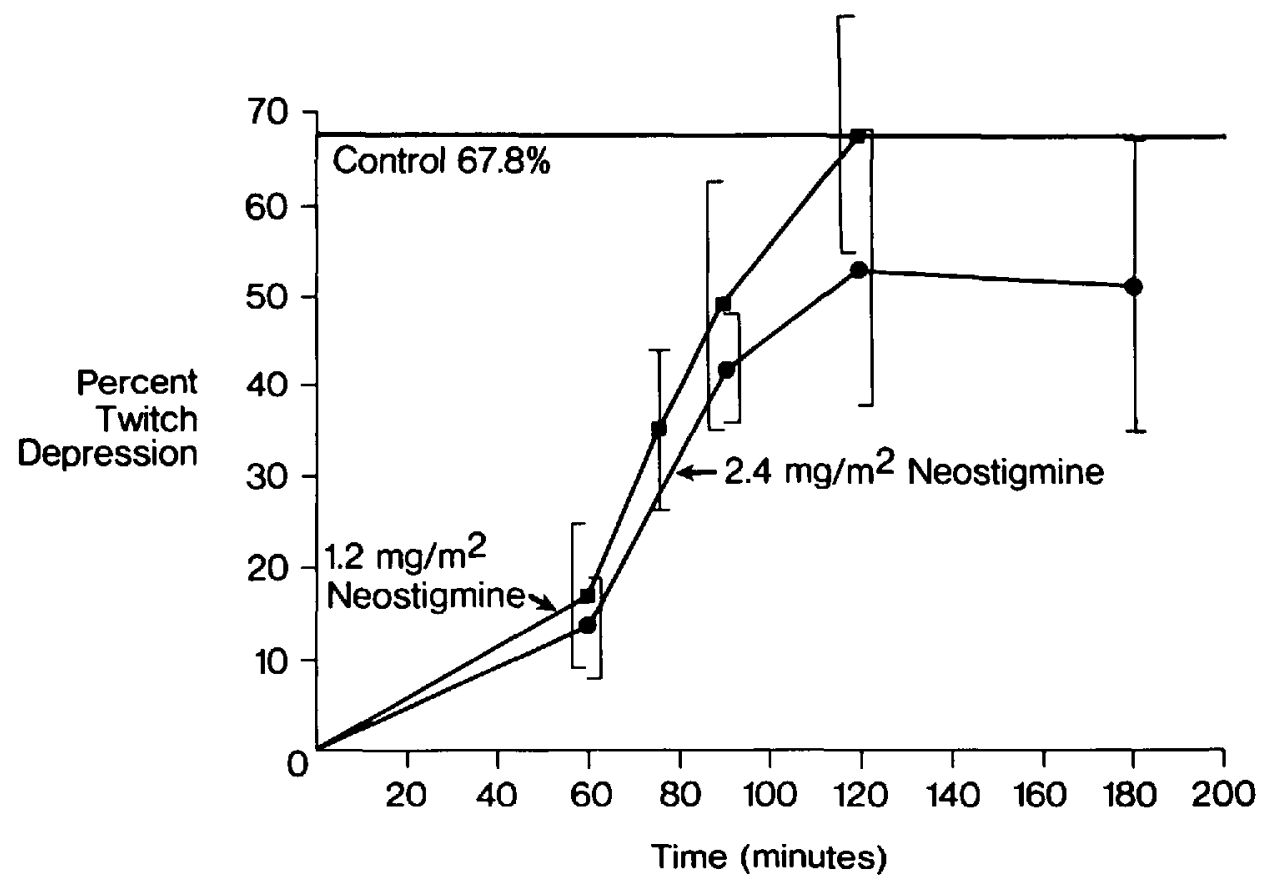

Figure 2. Percent twitch depression produced by d-tubocurarine $\left(4 \mathrm{mg} / \mathrm{m}^{2}\right)$ versus time for two doses of neostigmine. Each square or dot represents the mean $\pm 1 \mathrm{SE}$.

depression equivalent to that of control for almost 2 hours (116 min). (Figure 2) $2.4 \mathrm{mg} / \mathrm{m}^{2}$ BSA neostigmine (average dose $4.07 \mathrm{mg}$ ) interfered with the action of d-tubocurarine to produce twitch depression comparable to that of controls for over $180 \mathrm{~min}$. An interesting finding was the augmentation of twitch seen after the administration of neostigmine (Figure 3). Sometimes as much as a 50 per cent augmentation of twitch was obtained and this augmentation lasted for approximately 20 minutes. 


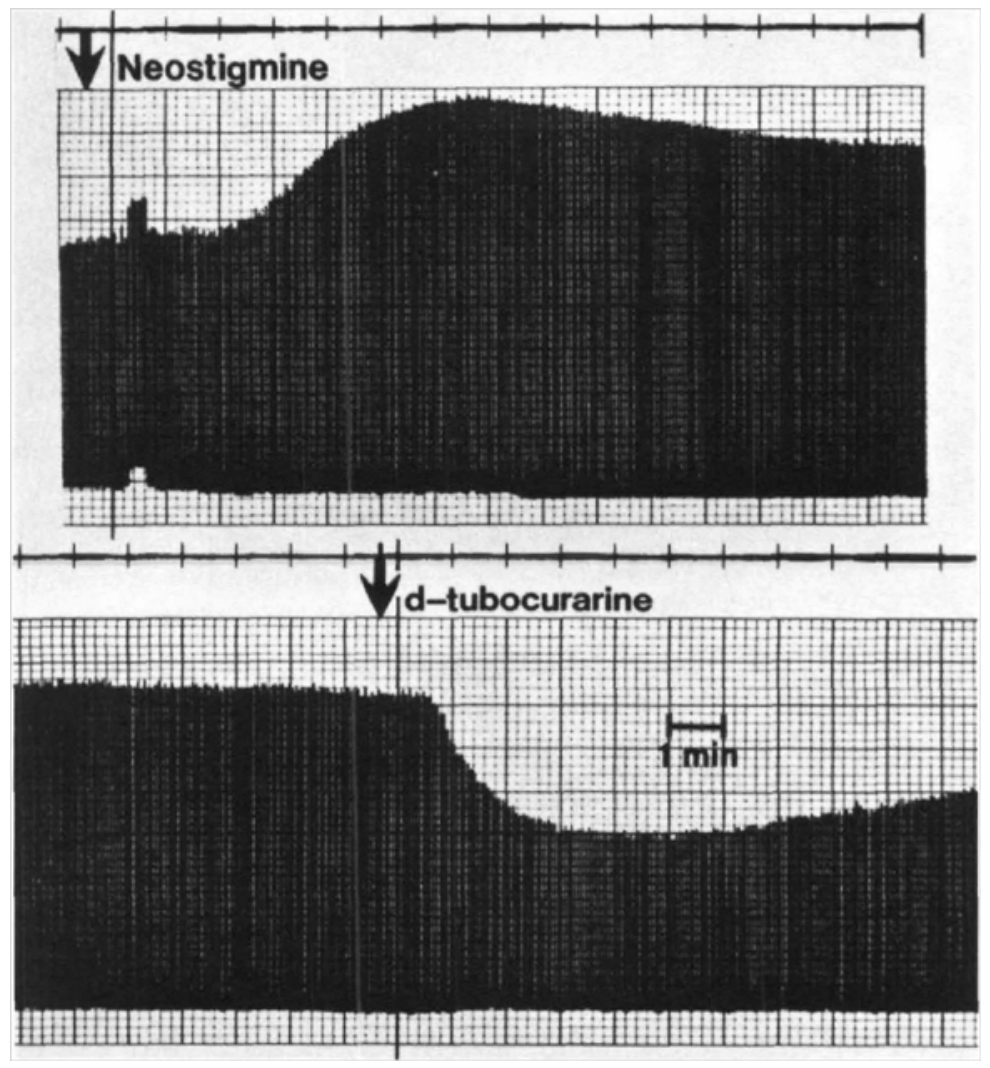

Figure 3. Augmentation of twitch height after administration of neostigmine. Note decreased slope of twitch depression after d-tubocurarine administration and rapid recovery indicating that $\mathrm{d}$-tubocurarine is being antagonized by neostigmine. The $\mathrm{d}$-tubocurarine was given 60 minutes after the neostigmine.

\section{Discussion}

In man the duration of action of neostigmine is 116 minutes and greater than $180 \mathrm{~min}$ respectively for the two doses selected for this study. This is longer than the $57.8 \pm$ S.E. 4.8 min duration reported by Miller and colleagues ${ }^{3}$ for $1.2 \mathrm{mg} / \mathrm{m}^{2}$ BSA neostigmine. They used a continuous d-tubocurarine infusion technique giving the neostigmine during the infusion and used 30 per cent return to the d-tubocurarine depressed twitch height as indicating duration of action. On the other hand we gave neostigmine prior to the d-tubocurarine and measured d-tubocurareinduced twitch depression. This difference in technique may account for the differences in duration of action reported in the two studies.

The total dose of neostigmine in the two neostigmine groups is roughly comparable to the two most commonly used dosages in clinical practice. The duration of action that we have determined for neostigmine may account for the recovery room bradycardia phenomenon frequently seen in patients who have received anticholinesterase medication. This bradycardia is usually otherwise unexplained and is successfully and uneventfully treated by the administration of atropine. 
If it is necessary to reparalyze a patient who has recently received neostigmine, larger doses than usual of the non-depolarizer may be necessary or a minimum of 2 hours should elapse in order for the patient to respond "normally" to nondepolarizing neuromuscular blocking drugs.

\section{REFERENCES}

1. Epstein, R.A. \& JaCkson, S.H. The effect of depth of anesthesia on the neuromuscular refractory period of anesthetized man. Anesthesiology 32: 494-499 (1970).

2. Walts, L.F. The "boomerang" - A method of recording adductor pollicis tension. Can. Anaes. Soc. J. 20(5): 706-708 (1973)

3. Miller, R.D., Van Nyhuis, L.S., Eger, E.I., et al. Comparative times to peak effect and durations of action of neostigmine and pyridostigmine. Anesthesiology 41:27-33 (1974). 